\title{
IDEAL IDENTITY CONSTRUCTION IN BEAUTY PRODUCT ADVERTISEMENT OF GARNIER
}

\author{
Rimah Hidayah', A. Dzo'ul Milal ${ }^{2}$ \\ State Islamic University of Sunan Ampel Surabaya ${ }^{1,2}$ \\ rimahidayah56@gmail.com ${ }^{1}$, a_milal@yahoo.co.id ${ }^{2}$
}

\begin{abstract}
This study aims at explaining how the advertiser constructs the ideal identity in the Garnier advertisement. It mainly focuses on the characteristics of language and other context used in the advertisement from a Critical Discourse Analysis (CDA) perspective. This is a descriptive qualitative method in which the data were collected from the beauty product advertisements of Garnier. The analysis is based on Fairclough's three dimensional models (textual features, discursive features, and social features). The findings of this study show that the ideal identity in the advertisement of Garnier is constructed by advertiser through the use of textual features and social features. The writer finds out that there is on-going struggle about how the advertisers construct the ideal identity in the modern society by giving the representation of attractive model and how they show their professionalism in technology by giving scientific evidence in their advertisements.
\end{abstract}

Keywords: ideal identity construction; advertisement; beauty product; Garnier; critical discourse analysis (CDA)

\section{INTRODUCTION}

Discourse of advertising plays a central role in shaping and constructing our attitudes as the audience and consumer. The advertisement has a language which implicitly constructs the public roles to make decision between right and wrong. Through language, discourse producers can create an image to the audience as the best and most powerful figure. Any discourse that is produced can be seen as the way producers convey their ideology and power.

Today, social construction of an ideal identity has become an important issue. The word "ideal" may sometimes be used to refer to physical appearance; which many people today have manipulated so that the first impression of the personality is valued from their physical appearance. In other words, we can say that women and men can be regarded ideal when their appearance is good looking. Such a condition is reflected by advertising phenomena in both electronic and non-electronic media that present the beauty product advertisements in which a stereotypical ideal is valued in terms of beauty and handsomeness.

In the era where beauty becomes the main object of commodity, for many people beauty products become a primary necessity that should be completed. This condition makes the companies of beauty products produce a creative promotion strategy to attract audiences. The promotion of their products is commercialized through televisions, magazines, and online mass media. The commercialization of beauty product is supposed to cast influence not only 
on women but also on men. Through textual and visual aspects, advertisers present a stereotypical ideal women and men to persuade their audience to buy their products. This perspective shows how social actors exercise their strength and construct power to manipulate women and men's beliefs.

For these reasons, this study explains about the ideal identity that is constructed by advertisers in the beauty product advertisement of Garnier by investigating either textual, visual, or social aspects. To analyze the problem above, this study uses Critical Discourse Analysis (CDA) as a useful tool.

This study was conducted to find out the answer to some problems as follows: How does the advertiser construct the ideal identity in the advertisement of Garnier? The answer to this question can lead to the other questions; (a) What are the textual features used in the advertisements of Garnier? (b) What are the discursive techniques employed in beauty product advertisements of Garnier to manipulate the consumers to buy the product? (c) What are the social features used in the advertisement of Garnier?

\section{REVIEW OF LITERATURE}

The detailed theoretical framework of this study can be seen in the following figure:

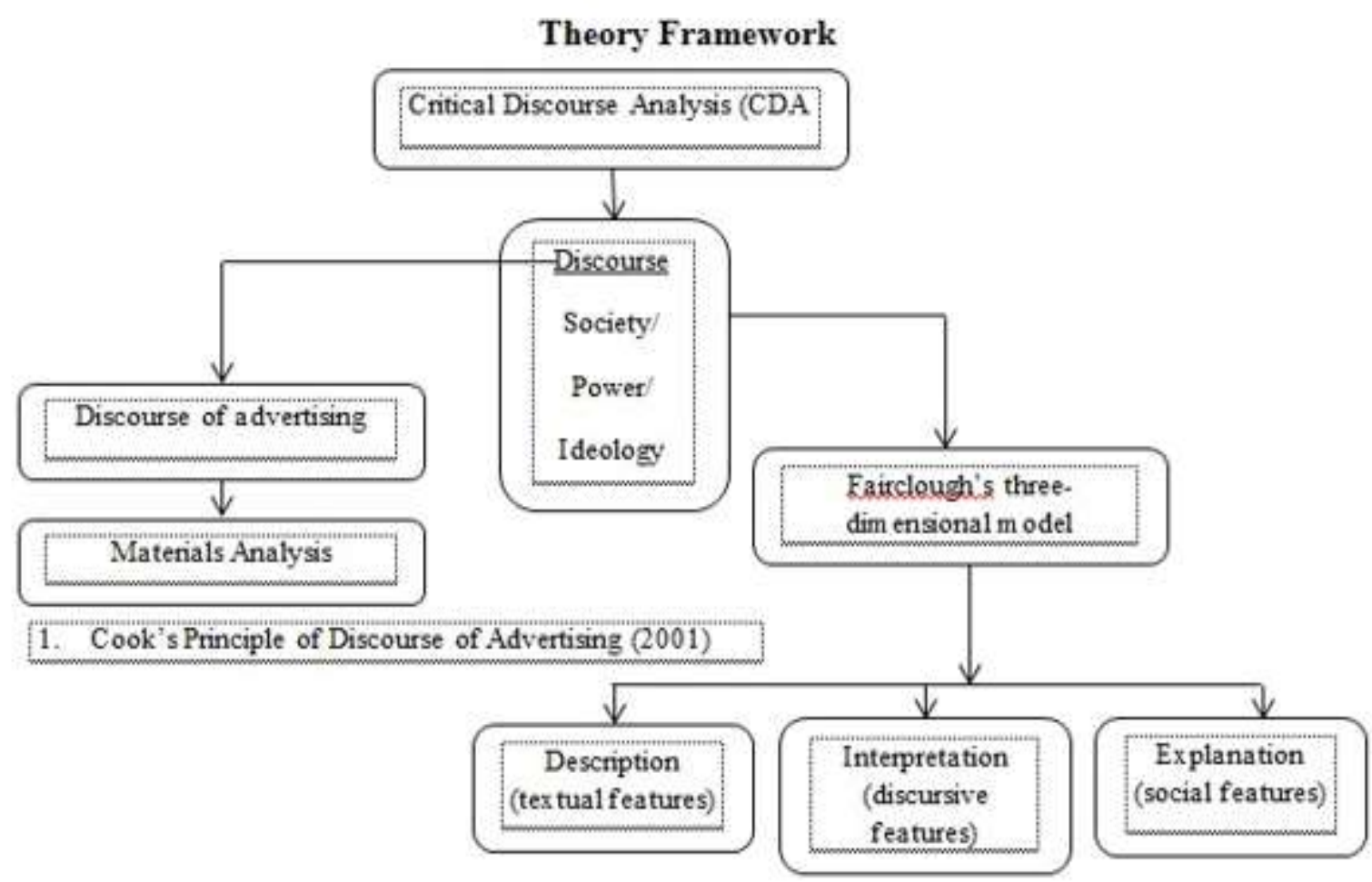

Figure 1: Fairclough's Three Dimensional Model of Discourse Analysis

To explain how the advertiser constructs the ideal identity in the advertisements of Garnier, the writer uses Critical Discourse Analysis (CDA), because Critical discourse 
analysis (CDA) is a form of research that analyzes the relationships between discourse, society, power and ideology (Fairclough, 1989). Fairclough (1989) also remarks that discourse as social practice has relation with text, interaction, and context. The analysis is based on Fairclough's three-dimensional model of critical discourse analysis as it focuses on the production and reception process of discourse than just analyzing the text. In addition, the writer also uses the concept of discourse analyses of advertising by Guy Cook (2001).

\subsection{Discourse of Advertising}

The discourse of advertising explores the language of advertising. The words of advertisements are not viewed in isolation, but in complex interaction with music, pictures, other text around them, and the people who make and experience them. The discourse of advertising mainly focuses on analyzing the language in advertisements which is not only concerned with language alone, but also with the other aspect around them (namely, context). In other words, language of advertisement examines not only the language in isolation but also in interaction with its surrounding contexts: where the communication occurs; who is communicating with whom and why; in what kind of society and situation; through what medium; how different types and acts of communication evolved, and their relationship to each other (Cook, 2001:3)

\subsection{Critical Discourse Analysis (CDA)}

Critical discourse analysis, often abbreviated to CDA, provides theories and methods for the empirical study of the relations between discourse and social-and- cultural developments in different social domains (Jorgensen and Louise, 2002:60). CDA is not only a description and interpretation of discourse in context, but also offers an explanation of why and how discourses work (Rogers, 2004:2). According to Fairclough (1989), CDA is a form of research that analyzes the relationships between discourse, society, power and ideology. It unveils the interests of a particular class enacted in the discourse.

Fairclough's $(1992,1995)$ analytic procedures include a three-tiered model that includes description, interpretation and explanation of discursive relation and social practices at local, institutional, and societal domains of analysis. The local domain may include a particular text (e.g., a newspaper, political speech, or school board meeting). The institutional domain is the next level of abstraction and includes the social institutions that enable and constrain the local domain (e.g., political affiliation of the newspaper company, schools). The societal domain is the next level of abstraction and includes the policies and meta-narratives that shape and are 
shaped by institutional and local domains. Each of these domains is in an ongoing dialogue with each other (Rogers, 2004:7).

\subsection{Fairclough's Three Dimensional Models}

Fairclough (1989) proposes three dimensions for every discourse analysis, notably a spoken or written text, a discursive practice and a social practice. The three dimensions consist of description, interpretation and explanation which have been mentioned in the previous explanation. Text and discursive practice represent two different dimensions in Fairclough's model and should be separated analytically. In the case of advertisement, the description is required to examine the textual features, such as vocabulary, grammar, syntax, sentence coherence and so on. Then, analysis of discursive practice focuses on how authors of texts draw on already existing discourses and genres to create a text, and on how receivers of texts also apply available discourses and genres in the consumption and interpretation of the texts (Jorgensen and Phillips, 2002:69). The last is explanation. This phase is emphasized to analyze the production of discourse and the social ideologies embedded in every interaction.

The general purpose of the three-dimensional model is to providean analytical framework for discourse analysis. The model is basedon the principle that texts can never be understood oranalyzedin isolation; they can only be understood in relation to websofother texts and in relation to the social context (Jorgensen and Louise, 2002:70).

\section{RESEARCH METHODS}

In this study, the researcher applied the descriptive-qualitative method. Krathwohl (1993) states that descriptive method is a kind of reserach method which has three main purposes of research: to describe, to explain, and to validate findings (Knupfer and Mclellan, 2001:1197). Meanwhile, qualitative approach is an approach which concerns with description and interpretation of the data rather than the counting of feature (Wray and Bloomer, 2006:97). By all of these, the researcher used descriptive and qualitative methods because the data analysis was presented through interpretation and the description of detail information about the ideal identity which is constructed by advertiser in the advertisement of Garnier. The writer also took some words of quotation rather than numerics as the data.

The data source of this study is the beauty product advertisements of Garnier that consists of face treatment advertisement (facial foam and facial cream) which was taken from web banner and Facebook banner of Garnier advertisements. To collect the data, the writer visited the website of Garnier Indonesia and facebook of Garnier Indonesia and Garnier Men Indonesia to take the figure of the advertisement of facial foam and facial cream that has been 
most frequently exposed on television. The writer took the figure by downloading the pictures on facebook and screen capturing the pictures in the websites. The data are the words, phrases, clauses, sentences that are used to construct ideal identity related to face treatment. Then, the writer analyzed the data based on the three levels of critical discourse analysis; textual features, discursive features, and social features.

\section{RESULTS AND DISCUSSIONS}

This part presents the findings of the research and the discussion on the main points in the findings.

\subsection{Findings}

In this part, materials analysis, textual analysis, discursive feature analysis, and social feature analysis are described.

\subsubsection{Materials Analysis}

This part is to uncover something beyond the research question but still related to the research topic. At this level, material analysis is needed to know about the substance and the situation of the advertisement of Garnier. Cook (2001) mentioned that advertising is a child of the secondary orality. Even when printed, it assumes the style of personal spoken communication. In this case, advertisements of Garnier are showed on television and World Wide Web banner. The main medium of the advertisement of this study was taken from the internet (website and Facebook). The broad access of the internet gives a greater control to advertiser in targeting the consumers. In addition, the website and Facebook also offer advertisers' unique opportunities to access particular groups and specialized demands.

\subsubsection{Textual Analysis}

In his three dimensional model, Fairclough (1989) distinguishes textual, discursive, and social features as three levels that can be analytically separated. In this section, the writer analysed what it should be looked for at each of the three levels, using data from the beauty product advertisements. At this level of analysis, the linguistic features such as vocabulary, grammar, types of speech act, and rhetorical devices employed in the advertisements are discussed.

\subsubsection{The Use of Pronoun}

The main aspect of this is how the producers narrate their texts so that the consumers can receive the message that they construct through their texts. In this level, the use of direct address in advertisement is needed for both ideological and practical reasons. The producers use second person personal or possessive pronoun such as "you" and "your" to address the 
consumers directly. The use of word "you" (or the possessive form, "your") is considered as higher value than the use of the word "I"; because the use of "I" is more personal and too individualized. This handling of people on an individual basis is referred as synthetic personalization (Fairclough, 1989:62). Based on the beauty product advertisement analyzed, the use of direct address is shown below:

Table 1. The Use of Pronoun

\begin{tabular}{lll}
\hline \multicolumn{1}{c}{ Example in the text } & Type of Advertisement \\
\hline - Kini cantikmu tampak sempurna: & $\bullet$ & Garnier Sakura White Serum \\
mulus, cerah merona & Cream \\
(Now your beauty is perfect: flawless, & \\
pinkish bright) & \\
\hline
\end{tabular}

\subsubsection{The Use of Imperative}

In advertisements, the producers need to persuade their consumers to buy or take an action about their products. Thus, advertisement usually uses imperative. By using imperative, the advertisers as producers try to make a closer relationship with their consumers. The following are the examples of imperatives used in the advertisements analyzed in this study:

Table 2. The Use of Imperative

\begin{tabular}{ll}
\hline \multicolumn{1}{c}{ Example in Text } & \multicolumn{1}{c}{ Type of Advertisement } \\
\hline - Ganti ke Sakura White Serum Cream & $\bullet$ Garnier Sakura White Serum \\
\hline dan buktikan bedanya! & Cream \\
(Move to Sakura White Serum Cream & \\
and proof its difference!) & \\
\hline - Dapatkan kulit putih cerah dan tanpa & $\bullet$ Garnier Light Complete White \\
\hline kilap dengan cepat! & Speed Multi-Action Whitening \\
(Get glowing white skin and mineral oil & Serum Cream \\
free fast!) & \\
\hline
\end{tabular}

\subsubsection{The Use of Syntax (Disjunctive)/Phrasal Sentence}

Another feature is the use of syntax (disjunctive), that is, sentences without verbs or subjects. These sentences consist of one or two grammatical items only (Kaur, 2013). Examples from the advertisements are shown in the table below:

Table 3. The Use of Syntax/Phrasal Sentence

\begin{tabular}{ll}
\hline \multicolumn{1}{c}{ Example in Text } & \multicolumn{1}{c}{ Type of Advertisement } \\
\hline 1. Cerah merona (pinkish bright) & Garnier Sakura White Serum Cream \\
2. Putih cerah (airy-light) & Garnier Light Complete White Speed \\
3. Formula baru (New formula) & Multi-Action Whitening Serum \\
4. Perlindungan SPF19 & Cream
\end{tabular}

(SPF19's protection) 
5. Lebih cerah (brighter)

6. Pori kecil (small pore)

7. Bebas minyak (mineral oil free)

8. Bebas kotoran (anti-muck)

9. Bersihkan komedo (forget mark)
Garnier Men Turbo Light Oil

Control Double White Icy Duo Foam

Garnier Men Turbo Light Oil

Control Anti-Blackhead Brightening

Icy Scrub

\subsubsection{The Use of Specific Vocabulary}

In advertisements, vocabulary is the most striking feature in expressing opinion about ideology of the advertisers. In this study, the use of adjective is inserted to give the positivity of the product. This condition is also made to create a fusion of contemporary advertising that will imbue the characterless product with desirable qualities (Cook, 2001:108).

Concerning the research question 1 , the ideal identity can be constructed through the use of adjectives. Those adjectives are used to give positive and negative affective meanings. The affective meaning displays consumer's positive and negative reviews about the product that is shown in the advertisement.

In this study, advertisement contains adjectives with both positive and negative connotations. The positive adjectives are related to the qualities of the product, whereas the negative adjectives are linked to the problem which may appear if the consumers do not use the product. The positive adjectives are: Cantikmu tampak sempurna (your beauty is perfect), Mulus (flawless), Cerah merona (pinkish bright), Menghaluskan pori wajah (minimize face pore), Putih cerah (airy-light), Komplit putih cerahnya (full of airy-light), Menyamarkan bintik hitam (forget blackhead), Wajah lebih cerah (face is brighter), Cantik natural (natural beauty), Mengurangi kekusaman kulit (minimize pallid-face), Meratakan warnakulit (minimize two-tone face), Wajah tampak putih cerah bersinar (face is white, shine and bright), Bebas minyak (mineral oil free), and Bebas kotoran (anti-muck). Meanwhile, the negative adjectives are: Wajah berjerawat (acne face), Noda bekas jerawat (acne spot), Minyak berlebih (over glossy), Warna kulit tidak merata (two-tone face), Wajah kusam (pallid-face), Kulit gelap (dark skin), Bintik hitam (black spot), Pori besar (big pore), and Pori tersumbat (gagged pore).

The ways the adjectives are used illustrate the positivity of the product. The use of emotive word or adjectival phrases can stimulate fantasy, dream, and desire. When consumers listen to these types of words, the advetisers want them to be there indirectly. From the use of positive and negative adjectives above, it is perceptible that the ideal, beautiful women and handsome men are those who have the criteria as follows: flawless, airy-light, small pore, no oily, no two-tone face, no pallid, no acne, and no black spot. 


\subsubsection{Formality and Grammar}

Another linguistic feature is the formality of vocabulary and grammar. The advertisments in this study used the vocabulary which comprises of formal and informal words. As for the grammar, the advertisements of the study used simple and declarative tenses. The types of verb, tenses, parallelism, modality, and punctuation is used to present a reality. The tenses used are mostly present tense, such as:

"SPF 21/PA+++nya melindungi dari sinar UV agar kulit tidak kembali gelap."

(SPF/21PA+++ protects you from UV beam to prevent you from skin darkness)

"Pelembab wajah sehari-hari yang memberikan coverage alami dan membuat wajah tampak cantik natural seketika."

(Daily face moisturizer that give natural coverage and make natural-beauty looking immediately)

There are also future tense sentences that are used to give a suggestion and recommendation about the benefit of using the product, such as:

"Noda hitam akan tampak semakin samar."

(Black spot will be disguised)

"Kulit akan semakin cerah hanya dalam 6 hari."

(skin face will be brighter in 6 days)

\subsubsection{Passive/Active Sentence}

In addition, the sentences mainly used in the discourse of these advertisments are active sentences. However, some passive clauses are also used in the advertisements as shown below:

"Ekstrak blueberry alami yang bantu lawan 12 masalah kulit yang disebabkan oleh jerawat dan minyak."

(Natural blueberry extract helps to prevent against 12 acne problems caused by acne and mineral oil)

\subsubsection{The Use of Conjunctive Adjunct}

In the advertisements of this study, conjunctive adjuncts are used in the text. According to Halliday (1994:36) the main types of conjunctive adjuncts are as follows:

Table 4. The Use of Conjunctive Adjunct

\begin{tabular}{ll}
\hline \multicolumn{1}{c}{$\begin{array}{c}\text { Conjunctive } \\
\text { Adjunct }\end{array}$} & Example in Text \\
\hline $\begin{array}{l}\text { Additive: dan } \\
\text { (and) }\end{array}$ & $\begin{array}{l}\text { Ganti ke Sakura White Serum Cream dan buktikan bedanya! } \\
\text { (Change to Sakura White Serum Cream and prove its }\end{array}$ \\
\hline
\end{tabular}




\begin{tabular}{|c|c|}
\hline & difference!) \\
\hline Adversative: - & - \\
\hline Conditional: - & - \\
\hline $\begin{array}{l}\text { Causal: } \\
\text { sehingga (so) }\end{array}$ & $\begin{array}{l}\text { Formulanya ringan mudah menyerap hingga ke dalam } \\
\text { lapisan kulit, sehingga bekerja dengan cepat. } \\
\text { (Its formula is easy to pervade into the deep skin layer, so it } \\
\text { works fast) }\end{array}$ \\
\hline \multirow[t]{2}{*}{$\begin{array}{l}\text { Purposive: agar } \\
\text { (in order to), } \\
\text { untuk (for) }\end{array}$} & $\begin{array}{l}\text { SPF21/PA+++nya melindungi dari sinar UV agar kulit tak } \\
\text { kembali gelap. } \\
\text { (TheSPF21/PA+++ protects you from UV beam to prevent } \\
\text { you from skin darkness) }\end{array}$ \\
\hline & $\begin{array}{l}\text { Facial foam pertama dari Garnier untuk pria yang } \\
\text { mengalami } 6 \text { tanda masalah jerawat. } \\
\text { (The first Facial foam from Garnier for men with } 6 \text { acne } \\
\text { indications) }\end{array}$ \\
\hline
\end{tabular}

\subsubsection{The Use of Repetition and Punctuations}

Repetition and punctuation of exclamation point (!) are also used in some advertisements in this study. The example of the repetition is presented below:

"Putih cerah hingga 3 tingkat \& tidak berminyak seharian. Komplit putih cerahnya!"

(Airy-light up to 3 levels \& not oily along the day. Full of airy-light!) - [Garnier Light Complete White Speed Multi-Action Whitening Serum Cream]

The use of repetition in one of the advertisements in this study has a function to emphasize the benefit of the product.

The punctuation is also evident in the advertisement. One of them is the use of exclamation point (!). The examples are shown below:

Table 5. The Use of Repetition \& Punctuation

\begin{tabular}{lll}
\hline \multicolumn{1}{c}{ Example in Text } & \multicolumn{1}{c}{ Type of Advertisement } \\
\hline - Komplit putih cerahnya! & (Full of airy-light!) & $\begin{array}{l}\text { Garnier Light Complete White Speed } \\
\text { Multi-Action Whitening Serum Cream }\end{array}$ \\
\hline - $\begin{array}{l}\text { Wajah lebih cerah, makin } \\
\text { banyak like! } \\
\text { (Face is brighter, get more like!) }\end{array}$ & $\begin{array}{l}\text { Garnier Pure Active 12 in 1 Multi Action } \\
\text { Foam }\end{array}$ \\
\hline - & Ajaib! (Magic!) & Garnier BB Cream Miracle Skin \\
- $\begin{array}{l}\text { Moisturizer-mu sehari-hari! } \\
\text { (Your daily moisturizer!) }\end{array}$ & Perfector \\
\hline - $\begin{array}{l}\text { Revolusi foam dua warna } \\
\text { dengan dua aksi! } \\
\text { (Two colors foam revolution } \\
\text { with two actions!) }\end{array}$ & Garnier Men Turbo Light Oil Control \\
- Tepat sasaran hilangkan minyak \\
$\begin{array}{l}\text { berlebih di wajah! } \\
\text { (Vanishing oily skin exactly!) }\end{array}$ & Garnier Men Turbo Light Oil Control \\
\end{tabular}


- Wajah bersih dari jerawat \& Garnier Men Acno Fight Wasabi Foam lebih cerah!

(Face is clear: no acne \& brighter!)

The exclamation point is a terminal punctuation mark that is used in place of the period to add emphasis or emotion. It turns simple statements into forceful ones, and remarks into exclamations or outbursts (Stilman, 1997:120).

\subsubsection{The Use of Parallelism}

Parallelism which is repeated use of similar grammatical structures is another device used in the advertisement. The following are examples of parallelism:

- Diperkaya dengan Sari Lemon, Salicylid Acid Derivative dan UVA/UVB Filters, yang formulanya memberikan manfaat komplit hingga 3 tingkat lebih putih cerah, menyamarkan bintik hitam dan bekasjerawat, 12 jam tanpa kilap, meratakan warna kulit dan efek tanpa minyak berlebih yang tahan lama.

(Enriched with Lemon Essence, Salicylid Acid Derivative and UVA/UVB Filters, the formula gives a complete benefit up to 3 levels more white and brighterlooking skin, forgets blackhead and acne spot, 12 hours anti-glossy, minimizes two-tone skin and effect longer of anti-glossy)

- Dengan kandungan sari lemon yang membantu mencerahkan dan mengurangi kekusaman kulit secara alami, Pigmen Mineral yang dapat meratakan warna kulit dan menyamarkan bekas jerawat \& noda hitam.

(With lemon essence that helps to brighten and minimize pallid-face naturally, Pigmen Mineral can minimize two-tone skin and forget acne spot \& black spot)

- Duo Foam pertamadari Garnier Men dengan Icy Mineralite Complex dan White Clay yang mampu membersihkan secara menyeluruh, membantu menyerap minyak berlebih dan mengangkat/menghilang kankotoran, sekaligus membersihkan pori-poriwajah.

(The first Duo Foam from Garnier Men with Icy Mineralite Complex and White Clay that can clear completely, help to absorb an over mineral oil and remove/forget the muck, also clear face pores)

\subsubsection{The Use of Modality}

Modality is also evident in the advertisement as shown below:

"Pigmen Mineral yang dapat meratakan warna kulit"

(Mineral pigmen that can minimize two-tone skin)

\subsubsection{The Use of Scientific Words}

In the advertisement of this study, the producer also uses scientific words to attract their consumers. In order to impress their consumers, the advertiser resorts the scientific words to reflect the professionalism and advancement in technology. Here are the examples of scientific words: Ekstrak sakura (Cherry blossom extract), Pore Smoothing Serum, 
SPF21/PA+++, Perlindungan SPF19 (SPF19's protection), White Speed TM Serum, Ekstrak Vitamin E, Sari lemon (Lemon essence), Salicylid Acid Derivative, UVA/UVB Filters, Vitamin C, Ekstrak Blueberry (Blueberry extract), Pigmen mineral, Icy Mineralite Complex, White Clay, Mineral-clay, Micro-beads, Herba repair, Purifying salicylic acid, Uji in Vitro, Proven Active.

\subsubsection{The Use of Number}

Numbers are also widely used in the advertisements as shown in the findings. For examples: Putih cerah hingga $\underline{3}$ tingkat, Putih cerah dengan cepat dalam $\underline{1}$ minggu, Hingga $\underline{3}$ tingkat putih lebih cerah, $\underline{12}$ jam tanpa kilap, Wajah lebih cerah dalam $\underline{6}$ hari, Lawan $\underline{12}$ tanda jerawat, Perlindungan $\underline{30 x}$ terhadap sinar matahari, Wajah tampak 1 tingkat lebih cerah, and Tangkis hingga $99 \%$ bakteri.

\subsubsection{The Use of Poetic Device}

Another linguistic feature is the use of poetic device, such as, alliteration. It is used to make it easy for people to remember the product. Here are the examples: $\underline{B}$ ebas minyak (mineral oil free), Bebas kotoran (dirt free), Bersihkan komedo (clean mark) - [Garnier Men Turbo Light Oil Control Anti-Blackhead Brightening Icy Scrub]

All these advertisements construct the ideal women and men in terms of beauty. The use of adjectives such as, flawless, airy-light, and bright, in almost all of the advertisements can create impression that beauty should be like that. In this case, the advertisements have a power to influence the women and men's behavior and manipulate them by creating a delusion.

\subsubsection{Discursive Feature Analysis}

Analysis of the discursive feature related to statement of the problem number 2 focuses on how the text is produced, how it is consumed, and how the power relations are enacted. In this study, the advertisers used various strategies in their discourse to attract consumers. The table below summarizes the strategies used.

Table 6. Discursive Features

\begin{tabular}{|c|c|c|}
\hline No & $\begin{array}{l}\text { Strategy Used in } \\
\text { Advertisement }\end{array}$ & Example in Text \\
\hline 1 & $\begin{array}{l}\text { Irrealist } \\
\text { representation }\end{array}$ & $\begin{array}{l}\text { - Kulit tampak sempurna seketika (Skin is perfect } \\
\text { immediately) } \\
\text { - Wajah tampak putih cerah bersinar (Face is white, } \\
\text { shine and bright) } \\
\text { - Wajah terlihat bersih dan lebih cerah serta terasa } \\
\text { dingin (Face is clear, brighter, and feel cold) }\end{array}$ \\
\hline 2 & $\begin{array}{l}\text { Scientific } \\
\text { evidence/ }\end{array}$ & $\begin{array}{l}\text { - SPF21/PA+++nya melindungi dari sinar } U V \\
\text { (Its SPF21/PA+++ protects from UV beam) }\end{array}$ \\
\hline
\end{tabular}




\begin{tabular}{|c|c|c|}
\hline & $\begin{array}{l}\text { clinical test } \\
\text { proof }\end{array}$ & $\begin{array}{l}\text { - Kini dengan White Speed TM serum } \\
\text { (Now with White SpeedTM serum) } \\
\text { - Proven Active teruji bekerja lebih cepa tkurangi } \\
\text { melanin hingga } 85 \% \\
\text { (Proven Active has tested to work fast in minimizing } \\
\text { melanin up to } 85 \% \text { ) } \\
\text { - Ekstrak blueberry yang bantu lawan } 12 \text { masalah kulit } \\
\text { (Blueberry extract helps to against } 12 \text { of skin } \\
\text { problems) }\end{array}$ \\
\hline 3 & Emotive words & $\begin{array}{l}\text { - Kulit mulus (flawless skin) } \\
\text { - Putih cerah (airy-light) } \\
\text { - Cantik sempurna (perfecting beauty) } \\
\text { - Cerah merona (pinkish bright) } \\
\text { - Bebas kilap (anti glossy) } \\
\text { - cantik natural (natural beauty) } \\
\text { - tidak berminyak (no oily) } \\
\text { - terasa dingin (feel cold) }\end{array}$ \\
\hline 4 & $\begin{array}{l}\text { Code switching/ } \\
\text { mixing }\end{array}$ & $\begin{array}{l}\text { - Makin banyak like! } \\
\text { - . . memberikan coverage alami } \\
\text { - Revolusi foam dua warna }\end{array}$ \\
\hline 5 & $\begin{array}{l}\text { Celebrity } \\
\text { endorsement }\end{array}$ & $\begin{array}{l}\text { - Pevita Pearce (actrees) } \\
\text { "Kini cantikmu tampak sempurna: mulus, cerah } \\
\text { merona (Now your beauty is perfect: flawless, } \\
\text { pinkish-bright)" } \\
\text { - Chelsea Islan (actrees) } \\
\text { "Tidak berminyak, komplit putih cerahnya! (No oily, } \\
\text { full of airy-light!)" } \\
\text { - Sheryl Shenafia (musicians) } \\
\text { "Wajah lebih cerah, makin banyak like! (Face is } \\
\text { brighter, get more like!)" } \\
\text { - Joe Taslim (Actor) } \\
\text { - Pasha (Vocalist of Ungu's band) }\end{array}$ \\
\hline
\end{tabular}

The main audiences of the beauty product advertisement are teenagers and adults who are aware and care about their appearances. In this case, the advertisers consciously use various strategies such as irrealist representation, scientific evidences, emotive words, code switching/mixing, and other devices to give facts about their product.

The first one is the use of irrealist representation. This strategy is used to create a delusion toward their consumers' mind. This strategy aims to attract and influence the consumers to buy the products. Furthermore, the advertisers also use celebrities as models for their beauty products to construct the consumer's mind that the beauty and handsomeness of the models is because they use their products. The advertisers also manipulate their consumers through their headline of their advertisements, such as: "Kini cantikmu tampak 
sempurna: mulus, cerah merona (Now your beauty is perfect: flawless, pinkish bright)". From that headline, the producers give a power toward the consumers' delusion that their product can make them perfectly beautiful. This strategy can present the ideal identity of women implying that perfect beauty is flawless and pinkish-bright.

As shown in the table above, the advertisers use emotive words in all their advertisements. They use that language to connote their power over beauty and handsomeness. It is also used to capture the consumer's mind about the positivity of the product in order to establish their place in the society.

The advertisers use such scientific evidence to present their professionalism and make perception that by using their product, their consumers will get a perfect beauty and handsomeness because the products are proven with a scientific evidences and provide many benefits. They invite their readers as consumers to a dream world of fantasy with sentence like "Cantikmu tampak sempurna (your beauty is perfect); Putih cerah hingga 3 tingkat (airylight up to 3 levels); Kulit tampak sempurna seketika (Skin is perfect immediately); Wajah terlihat bersih dan lebih cerah serta terasa dingin (Face is clear, brighter, and feel cold) and so on.

Code switching/ mixing is also used to increase a number of consumers and establish the power relationship in all communities that have a different language. The advertisers switch their language to establish a positive discourse among various communities. This is the way how the advertisers use various techniques to establish a power relationship and increase their production, consumption, and distribution in the society.

\subsubsection{Social Feature Analysis}

Analysis of the social feature is related to statement of the problem number 3 that explains the broad societal currents affecting advertisements. This level of analysis is also concerned with intertextual understanding that helps to understand the broad societal currents that are affecting the text being studied. This includes views on beauty by people worldwide and specifically Indonesian women and men's position within this practice. The beauty myth dates back to the past where women had also used various traditional products to enhance their appearance. They painted their faces using mud, clay, herbs, leaves, flowers and so on.

In this era, ideal identity in the term of beauty is socially constructed by capitalist community. For them, beauty is one of strategic areas that can be an object of commodity. For the reason, there are many beauty myths which are developed and socialized to create a desire on the women and men's behavior. The issues concerning women and men today such as 
having smooth skin, clear skin, bright skin and ideal appearance make cosmetics industry one of the fastest growing industries. So, beauty product advertisements today are able to have control or power over consumers. From the advertisements, both women and men measure themselves with a prototype of ideal figure created by advertisers through their advertising strategies.

Intertextuality occurs in advertising when advertisers use words from other discourses to attract readers, such as the use of words from science to advertise their beauty products. In this study, the examples of intertextuality can be seen on the use of scientific words, such as: Garnier Men Acne Fight advertisement - Diperkaya dengan Herba Repair dan purifying salicylic acid (Enriched with Herba Repair and purifying salicylic acid); Garnier Men Turbo Light advertisement - Ekstrak lemon dan scrubnya bantu eksfoliasi sel kulit mati pada lapisan epidermis (Lemon extract and its scrub help to exfoliation non-active skin cell in the epidermis); Garnier Light Complete Super Essense advertisement - Serum pencerah pertamadari Garnier yang memiliki kadar White Speed dan Vitamin C tertinggi (The first brightening serum from Garnier that have highest White Speed and Vitamin C degree); and so on.

The other intertextuality is the use of tagline of the brand, that is, Garnier - Sayangi dirimu (Love yourself). Through the use of tagline, the producers try to give an impression that to love ourselves, we have to take care of our face by using the product of Garnier. The tagline is also used to increase the product's sale and benefits.

In addition, the image of attractive models in advertisement evokes the power toward the consumers. The representation of models in the advertisements can evoke the perception of ideal women and men. In other words, the use of models is one of the strategies to stimulate consumers to buy their products by giving a claim that the problem can be solved and the beauty can be gotten through the use of the product. The way the producers present the famous actress and actor, such as Pevita Pearce and Joe Taslim, is the best way to maintain their power and establish their position in the society.

\subsection{Discussion}

Based on the findings related to the textual features analysis, the writer finds out that the ideal identity of women and men is constructed through the use of adjective. In this case, the advertiser of beauty product advertisement of Garnier gives a clear perception of ideal women and men by using adjectives, such as: flawless, airy-light, small pore, no oily, no twotone face, no pallid, no acne, and no black spot. 
From the discursive features analysis related to the second problem, moreover, the writer finds out that the advertisers consciously use various strategies such as irrealist representation, scientific evidences, emotive words, and code switching/mixing. This is how the producers use various techniques to establish a power relationship and increase their production, consumption, and distribution in the society. The writer also finds out that the most outstanding strategy used to promote the product and manipulate the consumers is the use of scientific evidence.

From the social features analysis related to the last problem, the writer finds out that the main aspect of social feature that represents the ideal identity of women and men is the use of celebrity endorsement in the advertisement of Garnier. There is an ongoing struggle about how the advertisers construct the ideal identity in the term of beauty and handsomemess in the modern society through the use of attractive models. The image of attractive models in the advertisement of Garnier can evoke the power toward the consumers where the ideal identity of women and men is constructed.

From the explanation above, the writer concludes that the ideal identity is constructed through the textual features and social features. Then, in the stage of discursive features of this study, the writer finds out that it only focuses on the strategy promotion which explains how the advertisers persuade and manipulate the consumers to buy the products.

Finally, the last discussion is about the issue concerning women and men today having smooth skin, clear skin, bright skin, and ideal appearance. Today, ideal identity in the term of beauty is socially constructed by capitalist community. For them, beauty is one of strategic areas that can be used as an object of commodity. For that reason, there are many beauty myths which are developed and socialized to create a desire on the women and men's behavior. In fact, many people have been manipulated to the extent that the beautiful women and handsome men should have flawless skin, clear skin or bright skin.

\section{CONCLUSION}

This study uses Critical Discourse Analysis as an approach of the study that lead to the analysis of three levels of discourse structure: textual, discursive, and social analysis. Based on the topic being analysed, the writer concludes that the textual analysis relates to the linguistic features such as vocabulary, grammar, types of speech act and rhetorical devices. Grammatically, the tenses used in the advertisement of this study are mostly present tense and use the active sentences. The use of conjunctive adjuncts, such as and, so, for are found in the advertisement. There is also modality (e.g. can), parallelism, and the use of poetic device 
(e.g. alliteration) found in the advertisement of this study. The advertisements of Garnier uses second person personal or possessive pronoun such as "you" and "your" to address the consumer directly.

The most important aspect of this stage is vocabulary, which is the most striking feature in expressing opinion about ideology of the advertiser. To construct the ideal identity of women and men, the advertisers use adjectives or emotive words such as flawless skin, pinkish bright, perfecting beauty, bright skin and others in all of their advertisements. These words are used to create a delusion toward the consumer's mind. These words also have a power to influence the women and men's behavior and manipulate them by creating a world of fantasy toward their mind.

The discursive analysis deals with the strategies used by advertiser to attract the consumers to buy their product. In this stage, the advertiser uses various strategies such as irrealist representation, scientific evidence, emotive words, and code switching/mixing. The use of various strategies is to establish a power relationship and increasetheir production, consumption and distribution in the society.

The last is social features analysis. This stage deals with the broader social practice of the advertisement. The representation of models in the advertisement of this study can evoke the ideal identity of women and men. Through the way in which the advertiser sets the layout of the model in the figure of the advertisement, it is perceptible that the advertiser wants to show the main aspect of the body of the model; that is face. Then, there is also ongoing struggle about how the advertisers construct the ideological of beauty in the modern society by giving the representation of models and how they show their professionalism in technology by giving the scientific evidence in their advertisements.

\section{REFERENCES}

Bazergan, E. (2014). Symbolic Language War in Celluler Advertisement (A Critical Discourse Analysis). International Journal of Science and Research (IJSR), 3(01). Retrieved from www.ijsr.net.

Cook, G. (2001). The Discourse of Advertising (2 $\left.2^{\text {nd }} E d\right)$. London and New York: Routledge.

Fairclough, N. (1989). Language and Power. Discourse, Common Sense and Ideology. Longman Group UK Limited.

Halliday, M. A. K. (1994). An Introduction to Functional Grammar. London: Edward Arnold. 
Iqbal, A., Malik H.D. \& Maria R.T. (2014 September). Exploitation of Women in Beauty Products of "Fair and Lovely": A Critical Discourse Analysis Study. International Journal on Studies in English Language and Literature (IJSELL), 2(09),122-131. Retrieved from www.arcjournals.org.

Jorgensen, M. and Louise P. (2002). Discourse Analysis as Theory and Method. London: Sage Publications.

Kaur K., Nalini A. \& Norimah M.Y. (2013). Beauty Product Advertisements: A Critical Discourse Analysis. Asian Social Science; Vol. 9, No. 3; 2013, Published by Canadian Center of Science and Education. Retrieved from www.ccsenet.org/ass.

Knupfer, N. N. \& McLellan, H. (2001). The Handbook of Research for Educational Communications and Technology. Bloomington: AECT.

Rogers, R. (2004). An Introduction to Critical Discourse Analysis in Education. (Ed). Mahwah, New Jersey: Lawrence Erlbaum Associates, Inc.

Shaikh, M, Dr. Faraz A.B., and Shafkat A.K. (2015). The Representation Of Men And Women In Advertisements: A Critical Discourse Analysis. The Women - Annual Research Journal Vol. 7, 2015.

Stilman, A. (1997). Grammatically Correct: The writer's essential guide to punctuation, spelling, style, usage and grammar. Cincinnati, Ohio: Writer's Digest Books.

Vahid, H. and Saeedeh E. (2012). The Power behind Images: Advertisement Discourse in Focus. International Journal of Linguistics, 4 (04). Retrieved from www.macrothink.org/ijl

Wray, A. \& Bloomer, A. (2006). Projects In Linguistics: A Practical Guide To Researching Language. New York: Oxford University Press Inc. 